\title{
Survey on Production, Marketing and Consumption of Gundpak: A Traditional Khoa Based Milk Product of Nepal
}

\author{
PUSHPA PRASAD ACHARYA ${ }^{1 *}$, GANGA PRASAD KHAREL ${ }^{1}$ and MEGHARAJ BHANDARI ${ }^{2}$
}

\author{
${ }^{1}$ Central Department of Food Technology, Dharan, Nepal \\ ${ }^{2}$ Department of Food Technology and Quality Control, Babar Mahal, Kathmandu
}

\begin{abstract}
This study aims to explore a traditional technology of Gundpak production, marketing and consumption in Nepal. The major ingredients used for Gundpak production are Khoa, sugar, ghee and gum, while minor ingredients are dried fruits, nuts, watermelon seeds, battisa powder, Jesthalangwadi etc. The annual production of Gundpak in Kathmandu valley has been estimated approximately 579.1 MT and sales about 550.4MT with a worth of NRs. 192.5 million. Mainly, there are two varieties of Gundpak named as normal and medicinal. Majority of Gundpak producers sale their product in an open tray called Kisti. However, some manufacturers started to pack the product into plastic containers with varying sizes. The shelf-life may vary i.e. one week in summer and two weeks in winter at ambient condition. The market products were found inconsistent in chemical compositions and other quality characteristics. Therefore, there is an urgent need of process optimization as well as quality standardization of Gundpak production in commercial scale.
\end{abstract}

Keywords: Indigenous food, Gundpak, Production and sales, Sensory quality, Battisa powder and Jesthalangwadi

\section{Introduction}

Nepal is rich in different traditional and indigenous foods, among them milk based products occupy the major volume of market share. Some major popular indigenous Khoa based milk products are Gundpak, Pustakari, Paneer, Khoa, Rasogolla, Lalmohan, Peda, Burfi, Kalakand, etc. Normally, such types of products are produced by some organized dairies and shops of Halwai community. Amongst all, Gundpak and Pustakari are locally manufactured in a cottage scale especially in Kathmandu valley by a Newari community. Nowadays, the other community peoples are also involved in the production of such products. Gundpak was first manufactured in Asan, Kathmandu, since 1933A.D. The term Gundpak was derived from the combination of two words Gund and Pakh (Gund means gum and Pakh means cooked).

The traditional dairy products such as Gundpak, Khawa, Sikarni and Tar are produced only in Nepal in the south Asian region (Aneja et al., 2002). The country people as well as the outsider especially Indian tourists, who pay their visits to Kathmandu use to buy Gundpak as a souvenir or gift for their family and neighbors. Due to its nutritious and deliciousness the Gundpak is gaining popularity and the demand of product has been increasing day by day not only inside but also outside the country.

Nepalese Mithais (traditional sweets) have been developed to preserve the nutritional quality of milk and to extend its shelf-life under ambient condition. Milk based sweets are mainly prepared from Khoa (partially heat-desiccated milk) and Chhanna (coagulated milk after draining of whey). In

\footnotetext{
*Corresponding author, E-mail: acharya2018@gmail.com
}

small city and big town the processing of sweets is done on a small-scale by the Halwai's (traditional confectioner), who are considered to be migrated from India from the immemorial time.

However, Gundpak prepared and sold in local markets greatly vary in their composition and nutritional quality. It is being a traditional product; there is no any specific recipe and process for making it. The selection of ingredients and production process varies from place to place and even family to family. They have their own logic on the quality characteristics (Acharya, 2008). The objective of this work is to find out the history of Gundpak production, existing production practice, and marketing and consumer preference of Gundpak.

\section{Materials and Methods}

A scheduled questionnaire was developed to collect the data of production and consumption of Gundpak in Nepal. The survey was conducted in the five districts viz. Kathmandu, Bhaktapur, Lalitpur, Banepa, Kavre (Banepa).The five respondents in each location were selected to collect the information regarding on personal views, knowledge and experience on Gundpak manufacturing, origin, the different ingredients used and their functions, recipe, methods of production, desirable quality characteristics and factors influencing them, production statistics, sales and marketing and storage practices. In this study, major focus was made to gather information from the persons, who involved in Gundpak production and selling in the market. The consumers are also selected on the basis of regular consumption of Gundpak. The data collected in the questionnaire were analyzed by using SPSS 13.0 for window software. 


\section{Results and Discussion}

\section{Proximate composition of Gundpak}

The following are the ranges of proximate composition of the some of the commercial samples of Gundpak.

Table 1. Proximate composition of a typical Gundpak

\begin{tabular}{lc}
\hline Parameters & Values ( \% dry basis) \\
\hline Protein & $10-16$ \\
Fat & $16-30$ \\
Ash & $2.6-3.6$ \\
Carbohydrates (by diff.) & $29-55$ \\
Energy value ( Kcal/100 g) & $330-360$ \\
\hline
\end{tabular}

\section{History and nomenclature of Gundpak}

According to Maskey (2009) (Owner of new Gundpak store at New Road, Kathmandu) his late grandfather Panna Lal Maskey was the first person to introduce Gundpak in Asan, Kathmandu in 1933AD. He had used an edible plant gum (also called Gund in Nepali) for cooking sweets; he coined the term Gundpak (Gund means gum and Pakh means cooked). In fact, Panna Lal Maskey was inspired by his maternal uncle, who was Baidhya (Ayurvedic Doctor) to prepare Ayurvedic medicine especially for lactating women with incorporating different herbal and medicinal plants. Later on he incorporated those herbals and medicinal plants products into Khoa cooking with Gund and it is called Gundpak, which has a dual effect of nutritional as well as medicinal purposes.

\section{Definition of Gundpak and its cultural importance}

At first, Sharma (2007) attempted to define Gundpak; however, he did not mentioned sugar as a main ingredient and watermelon seeds as an essential raw material for decorative toppings. Therefore, Gundpak definition can be modified as a Khoa-based dairy product made by cooking the blend of Khoa, sugar, ghee and fried Gund in ghee with proper agitation and mixing of ground dried dates (Chokada), nuts (cashew nut, almond, coconut, pistachio) and spices (cinnamon, clove, small cardamom, large cardamom) followed by topping with partly fried watermelon seeds and dry grapes. Herbal plants powder may be added as an optional ingredient for the development of characteristic flavor and therapeutic value of Gundpak.

According to some persons, the product is beneficial to lactating women, healing of wounds, cure of hemorrhage and white discharge. It is also believed that the product is useful for curing of miscarriage baby in women, tired and fatigue persons working in fields, who consume it at night time before going to bed. In earlier times the products was made Baidhya by using different medicinal plants called Battisa powder, so it has high nutritional as well as medicinal value. But now, the different other community also started its production without addition of such Battisa powder called normal Gundpak.
However, the product is now diverted to as simple sweets having high nutritional value but less therapeutic use.

\section{Classification of Gundpak}

There are different varieties of Gundpak available in the market. The varieties differ from place to place or community to community. The manufacturer has given the different name for Gundpak according to their way of mixing ingredients and tradition to manufacture and usefulness. Principally, there are two types of Gundpak. Among the respondents $(\mathrm{n}=180)$, the $45 \%$ respondents have no idea about the varieties of Gundpak, $44.4 \%$ was noted normal Gundpak found in the market. Similarly 1.1, 2.2 and 7.2\% were noted Sutkeri, spiced and medicinal, respectively.

Normal Gundpak: It is prepared by using Khoa, sugar, ghee, Gund, coconut and dry date powder and watermelon seeds. In normal Gundpak no Battisa powder has been added.

Medicinal Gundpak: It is intended to use for women during pregnancy and lactating period. In some places, it is also called Sutkeri Masala or Mishri pakh (In Newari: Phaku bansa pakh or Pokhuna jwala or Mishri pakh jwala). In the other word the Sutkeri medicine also called Battisa pakh. It is somewhat different in ingredient composition to that of Sutkeri masala. The Battisa powder and Jesthalangwadi are added to manufacture the Sutkeri or medicinal Gundpak. The proportion of addition may vary from manufacturer to manufacturer.

\section{Production technology of Gundpak}

\section{Major Ingredients and their functions}

The major ingredients for Gundpak are Khoa, sugar, gum (Gund), which are described as follows.

Khoa: The term refers to a traditional milk product originated in India, Nepal, Bangladesh and Pakistan. The importance of such milk products have been recognized since Vedic times (about five thousand years ago). Recently, the method of production technology of such indigenous product has been studied on scientific basis (De, 1983b). Traditionally, such indigenous dairy products have been manufactured in Halwai's shops and small dairy business (Patel, 1991). Consequently, there is a large variation in the quality of final products and storage stability (Patel, 1991; Suresh and Jha, 1994). Khoa is used as a base material for manufacturing the different sweets (Rajorhia, 2002). It contains several nutrients such as protein, fat, lactose, minerals. It gives consistency, firmness of body and improves the palatability of the product.

According to the PFA rules (1976), Khoa is the product obtained from cow or buffalo (even goat or sheep) milk or a combination thereof by rapid evaporation. It is directly consumed as a delicious and nutritious food. Buffalo milk is usually preferred than cow milk for Khoa making, since the 
former gives the greater yield and has a more desirable flavor, body and texture. Khoa is a product of great commercial importance as it forms an important base material for the preparation of varieties of indigenous milk sweets such as Burfi, Peda, milk cake, Gulabjamun etc., throughout the country (Rajorhia, 2002). It is also prepared and consumed domestically in hilly region of Nepal.

Khoa has a low shelf-life (three days during summer and six to seven days during winter) due to unhygienic preparation and handling, lacking of cool chain, high water activity and high protein and lacking of protective packaging. Since, it is not legally permitted to add any chemical preservative in Khoa, it is necessary to maintain a cool chain preferably around $2^{\circ} \mathrm{C}$ during storage and shipping (Rajorhia, 2002). For packing of Khoa a saran-coated films, laminates with aluminum foil, five layer co-extruded films and metalized polyester/ polypropylene etc., with desired functional properties can be recommended for alternative packaging materials depending upon the expected shelf life and marketing requirements. For export marketing of Khoa, the use of milk of excellent quality produced hygienically followed by instant chilling is considered essential (Rajorhia, 2002).

Browning of Khoa might results to decrease the consumption of products due to poor palatability, appearance, destruction of essential amino acids and vitamins as well as loss of biological value and digestibility. Browning may also produce some toxic substances and metabolic inhibitors (Gordon and Kalan, 1987; Gothawal and Bhavadasan, 1992). In milk products active sulphydryl groups serve as natural inhibitors in heat induced browning. However, such browning could be controlled in dairy products by limiting heat treatment (i.e. indirect heating system), moisture content, time and temperature of heating and storage condition (Nickerson, 1987, Ragendra et al., 1991).

The chemical analysis of Khoa showed moisture content, fat, protein, carbohydrate, total solid and ash as $24.8 \%, 31.23 \%$, $20.2 \%, 20.36 \%, 75.2 \%$ and $3.4 \%$ respectively. Likewise the $\mathrm{pH}$, acidity and free fatty acid were found to be $6.42 \%, 0.198 \%$, and $0.10 \%$ respectively (Agrawal, 2004).

Ghee: It is a clarified butter fat obtained from cow or buffalo milk. It is used in Gundpak as an ingredient in small quantity because Khoa itself contains a sufficient quantity of fat. Now a day, some manufacturers also use vegetable ghee instead of animal ghee. However, the product could be inferior.

Sugar: It is normally added to give the taste, color and body to the product. It is responsible for giving characteristic brown color and pleasing aroma (Miller, 1998).

Misri (Sugar crystal): Candy is related to the Sanskrit word as Khanda, which means the piece of sugar lump (Aneja et al., 2002).

Edible gum (Gum Arabic): Gum Arabic or gum acacia locally known as gum 'Hashab' is the most widely used and traded as water soluble gum. Gum Arabic is produced by Acacia Senegal, but gums obtained from other Acacias are also sometimes referred to the same name. There is a tendency by Indian authors, to specify Acacia Arabic as the source of gum Arabic. There are more than 120 other Acacia species that have been shown to differ greatly from gum arabic in terms of chemical composition and structure (Anonymous, 2010).

Gum Arabic introduced in medieval Europe through Arab, hence the name termed as gum Arabic. Its organized trade started in Sudan in 1820, which still dominates the world gum Arabic production to the extent of 70-80\%. Other gum Arabic producing countries are Chad, Senegal, Nigeria, Tanzania, Mali and Mauritania. It is exported as a primary product to industrial countries, mainly Western Europe and the USA (Anonymous, 2010).

Edible plant gum powder/grit in a plant or tree of Acacia is used as a binder in the preparation of Gundpak. The materials obtained from plant gums are Tragacanth, Karaya, gum Arabic and gum Ghatti. The principal compounds are áFucose, D-xylose, galacturonic acid, á-arabinose, D-galactose, rhamnose (mixed Ca, Mg and K salts) (Ranganna, 1986).

\section{Minor ingredients}

The minor ingredients for Gundpak preparation are fruits, nuts, watermelon seeds and different spices, which are described as follows.

Dry fruits and medicinal plant products: The different dry fruits and herbal products can be used for the preparation of Gundpak, such as dry grapes, coconut, date, cashew nut, almond, pistachio, small and large cardamom, seeds (Ash gourd, Cucumber and Water melon), and spice powder.

Almonds (Badam): It has extensive use in various forms in different traditional Indian milk products like Kheer, Burfi and confections. It has a high nutritive value and provides a typical flavor and richness to food products. They are mostly used as a minor ingredient to bring desirable aroma, flavor, crispness, tenderness, rich color to serve or garnish (Aneja et al., 2002). These are mainly consumed for their cooling and healthpromoting qualities. Similarly, almond Burfi, made from almond paste, sugar and Khoa, is a connoisseur delight. It is served on special occasions. Broken or slivered nuts are used mainly to garnish dairy products like Kheer, beverages, sweets and frozen desserts (Aneja et al., 2002). It is used as an ingredient for Gundpak production.

Kaju (Cashew nut): These are kernels of dry seeds of Anacardium occidentale curved in shape of the letter ' $C$ '. The unprocessed nut gives a taste of starchy with the characteristic flavor of cashew. It is dried and sometimes smoked to give a shelf-life of 6 to 7 months, when kept in dry. Cashew seeds are picked when fully ripe or after falling to the ground. Cashew kernels are extracted from cashew nuts by roasting, shelling and peeling (Aneja et al., 2002). 
Dried coconut kernel: The presence of more than 6-7\% of sucrose is an indication that sugar has been added. Protein content of dried coconut is about $6 \%$, unavailable carbohydrate content about $18 \%$, crude fiber about $4 \%$ along with some mineral contents (Aneja et al., 2002).

Pistachio (Pista): Because of its characteristics flavor and nutritive value, it can be used in appreciable amounts in the manufacture of milk based sweets and frozen desserts. It contains $20 \%$ protein, $53 \%$ fat, $15 \%$ sugar, $6.1 \%$ moisture, $3.1 \%$ fiber and $3.1 \%$ total ash. It also contains most of the vitamins like vitamin $\mathrm{A}$, and $\mathrm{B}_{2}$ are in appreciable quantity. One hundred of pistachio generates $630 \mathrm{Kcal}$. It has rich buttery flavor and vivid green color provide exceptional flavor, texture and color to many food products. Pistachio is used as a natural thickener, emulsifier and binder too. As a heavy cream replacer, it can help to reduce saturated fats and eliminate cholesterol in confections. Kernels can be used in whole, dried, sliced and silvered forms (Aneja et al., 2002).

Walnuts: Walnuts are a good source of several vitamins including thiamin, vitamin B and folacin. They are naturally low in sodium and carbonate substantial amounts of dietary fiber. They contain no cholesterol as they are high in unsaturated fats. Walnuts are used in many indigenous dairy products. They add a slightly bitter taste that contrasts well with the sweetness of dairy products. They also make excellent toppings by giving of unique crunch and the desired mouth feel to the consumers (Aneja et al., 2002).
Raisins (Kishmish): The word 'raisin' comes from the French word 'raisin sec' meaning dry grape. In the present context, raisin refers only to the 'seedless dry grape', produced by natural shade drying of grapes. Raisins are very sweet, small, round plump and light brown in color with a coat of natural bloom. Raisins are extensively used in India to prepare various sweets and bakery products, whereas lexiors (monakka, dry seeded grapes) are used in Ayurvedic medicines (Aneja et al., 2002). It has been used for the decorative toppings in Gundpak production.

Small cardamom: It is used in most of the indigenous milk products like Kheer, Payasam, Phirni, Burfi, Peda, Gulabjamun, Sandesh, Shrikhand, etc., to impart flavor an enrich taste. Large cardamom can also be used in the substitution of small cardamom. It provides taste, aroma or flavor to the products (Aneja et al., 2002). It gives the characteristic flavor and taste to the Gundpak.

Battisa powder: The Battisa powder contains locally available medicinal and herbal plants together. It is incorporated o make especial kind of Gundpak suited for pregnant and lactating women. It is also claimed that herbal Gundpak possess beneficial or curative effect to the women who have health problems like white discharge, excessive bleeding, pain in lower abdomen, miscarriage, etc. So, it has been used not only as food but also as Aurvedic medicine. The amount of Battisa powder mixed in Gundpak production varies from producer to producer. The different herbal plants with their botanical and Sanskrit names used in the Battisa powder preparation are given in Table 2 .

Table 2. Locally available medicinal plants used in Battisa powder

\begin{tabular}{|c|c|c|c|c|}
\hline S.N & $\begin{array}{l}\mathbf{L N}=\text { Local name }^{\mathrm{a}} \\
\mathbf{S N}=\text { Sanskrit name }^{\mathrm{d}}\end{array}$ & English name $^{b}$ & Botanical name ${ }^{c}$ & Parts used ${ }^{e}$ \\
\hline 1 & $\begin{array}{l}\mathrm{LN}=\text { Amala } \\
\mathrm{SN}=\text { Adiphala, Amalaki }\end{array}$ & $\begin{array}{l}\text { Emblic myrobolon } \\
\text { Gooseberry }\end{array}$ & $\begin{array}{l}\text { Phyllanthus emblica Linn. } \\
\text { Eblica officinalis Gaertn. }\end{array}$ & Fruits \\
\hline 2 & $\begin{array}{l}\mathrm{LN}=\text { Arjun } \\
\mathrm{SN}=\text { Arjunah, Kakubhah }\end{array}$ & Arjun & $\begin{array}{l}\text { Terminalia arjuna (Roxb.) } \\
\text { Pentaptera arjuna }\end{array}$ & Bark \\
\hline 3 & $\begin{array}{l}\mathrm{LN}=\text { Ashwogandha* } \\
\mathrm{SN}=\text { Varahkarni, } \\
\text { Asvagandha }\end{array}$ & Winter celery & $\begin{array}{l}\text { Withania somnifera Linn. } \\
\text { Dunal }\end{array}$ & $\begin{array}{l}\text { Roots, leaves, } \\
\text { fruits and seeds }\end{array}$ \\
\hline 4 & $\begin{array}{l}\mathrm{LN}=\text { Baayubidanga } \\
\text { SN=Vidangah, Vellah }\end{array}$ & Embelia & $\begin{array}{l}\text { Embelia ribes Burm. F. } \\
\text { Embelia tsjeriam cottam } \\
\text { Embelia robusta } \mathrm{Roxb} .\end{array}$ & Fruits \\
\hline 5 & $\begin{array}{l}\mathrm{SN}=\text { Barro } \\
\mathrm{SN}=\text { Aksha, Anilaghnaka }\end{array}$ & $\begin{array}{l}\text { Belliric myrobolon } \\
\text { Bustard myrobolon, } \\
\text { Bedda nuts }\end{array}$ & Terminalia bellirica & Fruits \\
\hline 6 & $\begin{array}{l}\mathrm{LN}=\mathrm{Bel} \\
\mathrm{SN}=\text { Bilva shreephal }\end{array}$ & $\begin{array}{l}\text { Bel tree, Bengal } \\
\text { quince }\end{array}$ & $\begin{array}{l}\text { Aegle marmelos (Linn.) } \\
\text { correa }\end{array}$ & $\begin{array}{l}\text { Roots, leaves and } \\
\text { fruits }\end{array}$ \\
\hline
\end{tabular}


$\mathrm{N}=\mathrm{Bhringaraa}$ $\mathrm{SN}=$ Bhringarajah

Tekarajah

\begin{tabular}{|c|c|}
\hline 8 & $\begin{array}{l}\mathrm{LN}=\text { Daalchinee } \\
\mathrm{SN}=\text { Tvak, Chocham, }\end{array}$ \\
\hline 9 & $\begin{array}{l}\mathrm{LN}=\text { Gurjo or Gudchi } \\
\mathrm{SN}=\text { Amritavalli,Guduchi, }\end{array}$ \\
\hline 10 & $\begin{array}{l}\mathrm{LN}=\text { Gokhur } \\
\mathrm{SN}=\text { Gokshura, } \\
\text { Ikshugandha }\end{array}$ \\
\hline & LN=H̆arro \\
\hline
\end{tabular}

$12 \mathrm{LN}=$ Jethi madhu $\mathrm{SN}=$ Yastimadhuh,Madhukah

13 Jira

$14 \quad \mathrm{LN}=\mathrm{Jwaanu}^{*}$

$\mathrm{SN}=$ Ajmoda, Yavani

15 Kaafal

$16 \quad \mathrm{LN}=$ Kaauso

$\mathrm{SN}=$ Adhyunda

Atmagupta

Kapikachhu

Shukhashimbha

17 Kachur

18 LN=Koiraalo

$\mathrm{SN}=$ Kachnar,

Kovidarah

$19 \mathrm{LN}=$ Kurilo/Sata

$\mathrm{SN}=$ awarSatawari, Abhiru

20 LN=Majitho

$\mathrm{SN}=$ Manjistha,

Yojanavalli

$21 \quad \mathrm{LN}=$ Marich

$\mathrm{SN}=$ Maricham

22

$\mathrm{LN}=$ Naagakeshar

$\mathrm{SN}=$ Nagapuspah,

Nagakesharah

23 Naagarmoothe
Trailing eclipta

Cinnamon

Heart leaved

moonseed

Calthrops

Chebulic

myrobolon

Black myrobolon

Liquorice

Cumin

Ajowan, Lovage

Box myrtle, Bay berry

Common cowitch

Mucuna nigricans (Lour) steud. Mucuna imbricate DC.

Mucuna pruriens Linn.

Dolichos pruriens Linn.

East India arrowroot

Zeodary

Curcuma angustifolia Roxb.

Rhizome

Curcuma zedoaria Rosc.

Rhizome

Mountain ebony, Bauhinia variegata linn.

Variegated bauhinia

Bauhinia candida Alton.

Wild asparagus

Asparagus racemosus Willd

Tubers

Madder

Rubia manjith Roxb. Ex Root

fleming

Black pepper, Pipper nigrum Linn.

Pepper

Iron wood tree

Mesua ferrea Linn.

Bark, leaves,

Flowers \& oil

Cyperus scariosus $\mathrm{R}$. Br. 
Naagarmoothe

24

$\mathrm{LN}=$ Paasaanved

Pakhan bedh

$\mathrm{SN}=$ Pasanved

25

$\mathrm{LN}=$ Pipalaa*

$\mathrm{SN}=$ Granthika, Magadhi

26

$\mathrm{LN}=$ Punarnavaa

$\mathrm{SN}=$ Punarnava, Sothagni

$27 \quad \mathrm{LN}=$ Sataawar/ Bankurilo

$\mathrm{SN}=$ Satawari, Abhiru

28

Shankhapuspee

29

$\mathrm{LN}=\mathrm{Simal}$

$\mathrm{SN}=$ Mocha, Kantakdruma

30

$\mathrm{LN}=$ Sutho $^{*}$

$\mathrm{SN}=$ Adrakam

$31 \quad \mathrm{LN}=$ Tej pat ${ }^{*}$

$\mathrm{SN}=$ Tamalpatra

\section{or Rockfoil}

Coelus

Long pepper

Spreading Hogwood

Wild asparagus

Butterfly pea

Red cotton tree

Ginger

Indian cassia lignea

32

Thulo okhati
Cyperus scariosus $\mathrm{R}$. Br.

\section{Bergenia ciliata Rootstock}

Coleus forskohlii briq

Coleus barbatus (Andrews)

Benth

Piper longum linn.

Roots and fruits

Whole plant

Asparagus racemosus Wild. Tubers

Clitoria ternatea linn.

Jernatea vulgaris Humb.

Seeds, roots and root bark

Bombax cieba Linn.

Flower

Zingiber officinale Rosc.

Amomum zingiber linn.

Rhizome

Cinnamomum tamala (Buch. - Roots, Leaf

Ham.) Nees and Eberm

Cinnamomum albiflorum Nees

Astilbe rivularis Bush

Rhizomes

\section{Recipe for Gundpak}

According to the different producers, a general recipe for Gundpak production is given in Table 3.

Table 3. General recipe of Gundpak

\begin{tabular}{ll}
\hline Ingredients & Parts \\
\hline Khoa & 100 \\
Sugar & $30-35$ \\
Ghee & $5-10$ \\
Gund (gum) & $1-5$ \\
Fruits, nuts and spices & $5-10$ \\
\hline
\end{tabular}

Along with this recipe, the fruits like dry dates, dry grapes and nuts like cashew nut, coconut, ground nuts, pistachio, and spices like large cardamom, cinnamon, clove, cinnamon bark etc are used in different proportions.

As per the opinion of some manufacturers, the traditional Gundpak production process is given in the Figure 1. They do not follow the same procedure all the times. The recipe used depends on availability of raw materials or manufacturers' interest.
Source : ${ }^{\mathrm{a}, \mathrm{b}, \mathrm{c}, \mathrm{d}, \mathrm{e}}$ Annonymous, 2007.

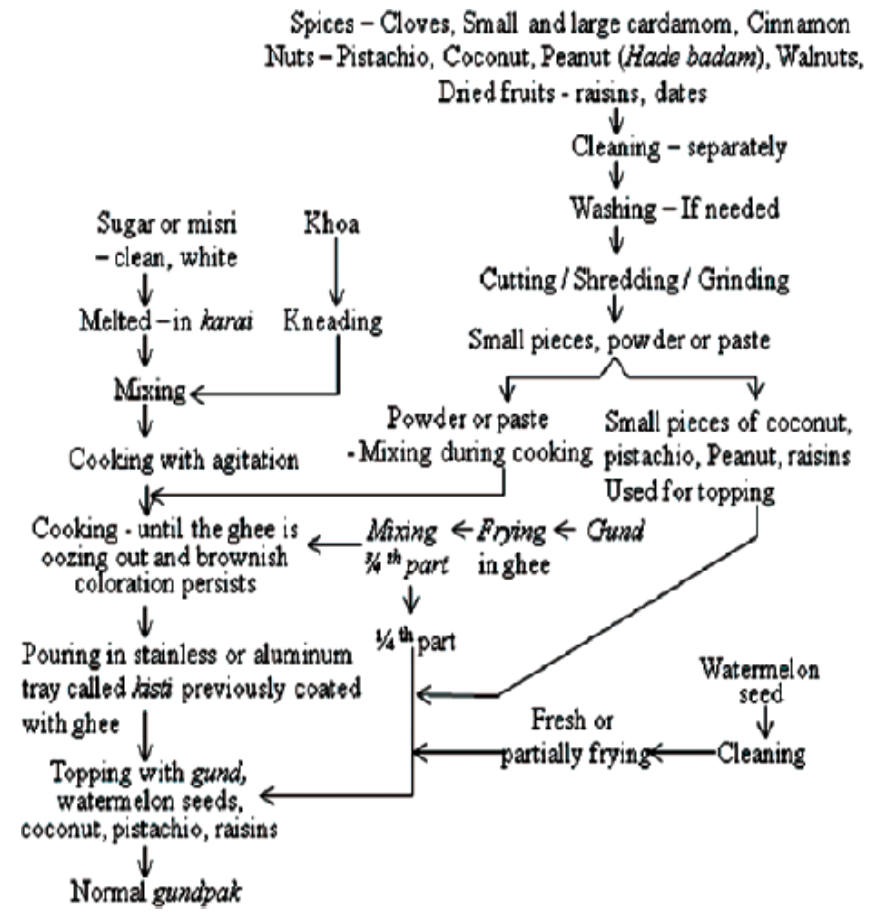

Figure 1. Flow-chart for the traditional production method of normal Gundpak 


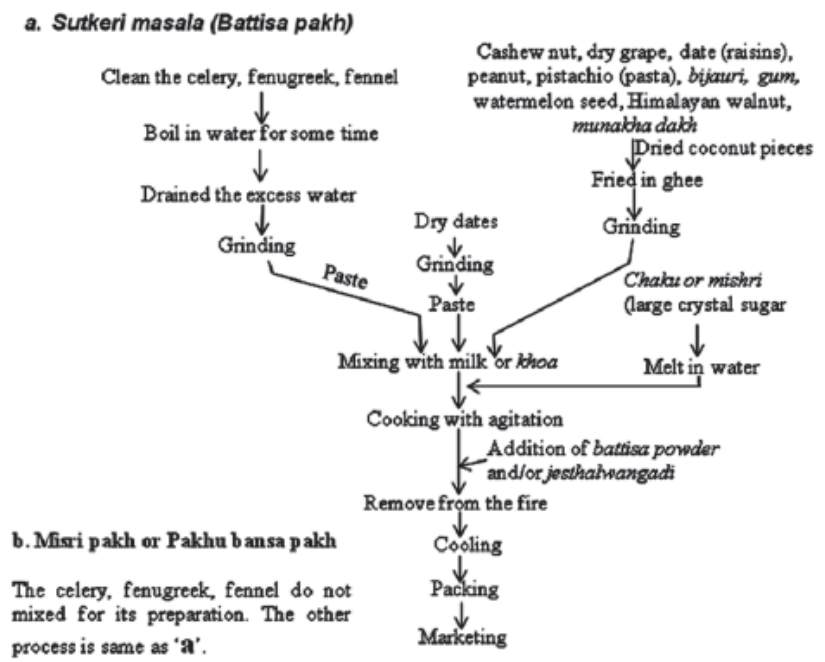

Figure 2. A traditional method for the preparation of Sutkeri masala and Mishri pakh medicinal Gundpak

For the preparation of medicinal Gundpak the same process is applied as normal Gundpak except that Battisa powder and Jesthalangwadi powder are mixed during cooking. The composition of Battisa powder and Jesthalangwadi is given in Table 2 and 4 respectively.

\section{Technology of medicinal Gundpak}

The main recipe for Gundpak is Khoa and others are sugar, ghee, cashew nut, dry grapes, edible gum, Battisa powder, Jesthalangwadi, Gund, watermelon seeds, etc. According to Shrestha (2009), the following technologies are normally used for preparing Gundpak in Patan, Mangal Bazzar.

Some manufacturers used greater number of medicinal plants as per the availability and known effect (Table 4).

Jesthalangwadi: It is another type of powder made by mixing of different medicinal and herbal plants and used to prepare medicinal (Sutkeri) Gundpak (Table 4).

Equipment and accessories: Equipments used for the production of Gundpak are iron open pan (Karai) or open kettle, frying pan, stirring ladle, spoons, stoves, trays (aluminum or stainless steel), knife, balance, thermometer (0$200^{\circ} \mathrm{C}$ ), disposable plates, etc. However, simple Karai, ladle, stoves are used in traditional method.

Cooking fuel: The cooking fuels are wood, kerosene stove, diesel stove, gas stove. Its production is mainly concentrated in the urban areas so because of scarce of wood, now a day's majority of producers use gas stove.

Table 4. Medicinal and herbal plants included in the preparation of Jesthalangwadi

\begin{tabular}{|c|c|c|c|c|}
\hline S.N. & $\begin{array}{l}\text { LN=Local name } \\
\text { SN=Sanskrit name }\end{array}$ & English name & Botanical name & Parts used \\
\hline 1 & $\begin{array}{l}\text { LN=Alainchi } \\
\text { SN=Aindri, Sithulaela }\end{array}$ & $\begin{array}{l}\text { Large } \\
\text { cardamum }\end{array}$ & Amomum sabulatum Roxb. & Fruits and seeds \\
\hline 2 & $\begin{array}{l}\text { LN=AshwogandhaaSN=Asvaga- } \\
\text { ndha, Varahkarni }\end{array}$ & Winter cherry & $\begin{array}{l}\text { Withania sominifera (Linn.) } \\
\text { Dunal }\end{array}$ & $\begin{array}{l}\text { Roots, Leaves, fruits } \\
\text { and seeds }\end{array}$ \\
\hline 3 & $\begin{array}{l}\text { LN=Bhringaraj } \\
\text { SN=Bhringarajah } \\
\text { Tekarajah } \\
\text { Pitabhringarajah } \\
\text { Pitabringa }\end{array}$ & $\begin{array}{l}\text { Trailing edipta } \\
\text { Pilabhangara }\end{array}$ & $\begin{array}{l}\text { Eclipta prostrate (Linn.) } \\
\text { Eclipta alba (Linn.) Haask. } \\
\text { Wedelia calendulacea Less } \\
\text { Wedelia chinensis (Osbeck) } \\
\text { Merrill }\end{array}$ & Whole plant \\
\hline 5 & $\begin{array}{l}\mathrm{LN}=\text { Chandan(Shreekhanda) } \\
\mathrm{SN}=\text { Srikhandam }\end{array}$ & Sandal wood & Santalum album Linn. & Heartwood \\
\hline 5 & $\begin{array}{l}\text { LN=Jaifal/ Jaaipatree } \\
\text { SN=Jatiphalah }\end{array}$ & Nutmeg & Myristica fragrans Houtt. & Seeds \\
\hline 6 & $\mathrm{LN}=$ Jatamashi & Spikenard & $\begin{array}{l}\text { Nardostachys grandifora DC. } \\
\text { Nardostachys jatamansi DC }\end{array}$ & Roots and rhizome \\
\hline 7 & $\begin{array}{l}\mathrm{LN}=\text { =Kankol(Thulopipla) } \\
\mathrm{SN}=\text { Kankolam }\end{array}$ & Java pepper & Pipercubebalinn. f. & Dried unripe beries \\
\hline 8 & $\begin{array}{l}\text { LN=Krishna Jirak/ } \\
\text { Jhusetil }\end{array}$ & Black niger & $\begin{array}{l}\text { Guizotia abyssinica (Linn. f.) } \\
\text { Cass. }\end{array}$ & Seed oil \\
\hline 9 & $\begin{array}{l}\text { LN=Kush/Usir } \\
\text { SN=Darbha, Yagyika, }\end{array}$ & Sacrificial grass & Desmostachys pipinnata & Whole plant \\
\hline 10 & $\begin{array}{l}\mathrm{LN}=\text { Marich } \\
\mathrm{SN}=\text { Maricham }\end{array}$ & Black pepper & Pipernigrum Linn. & Fruits \\
\hline 11 & $\begin{array}{l}\mathrm{LN}=\text { Mungrelo } \\
\mathrm{SN}=\text { Krishna jira }\end{array}$ & Black aumin & Nigella sativa Linn. & Seeds \\
\hline 12 & $\mathrm{LN}=$ Nilo Kamal & Blue water lily & Nymphaea stellata Willd. & Whole plant \\
\hline 13 & $\begin{array}{l}\text { LN=Rukh Keshar } \\
\mathrm{SN}=\text { Nagapuspah, } \\
\text { Nagakesharah }\end{array}$ & Iron wood tree & $\begin{array}{l}\text { Mesua ferrea } \operatorname{Linn} \\
\text { Mesua nagassarium (Burm. f.) } \\
\text { Kosterm }\end{array}$ & $\begin{array}{l}\text { Bark, Leaves, } \\
\text { flower and oil }\end{array}$ \\
\hline 14 & $\begin{array}{l}\mathrm{LN}=\text { =Sukmel } \\
\mathrm{SN}=\text { Ela, Trutih }\end{array}$ & $\begin{array}{l}\text { Small } \\
\text { cardamum }\end{array}$ & Ellettaria cardamomum Maton & Seeds \\
\hline
\end{tabular}

(Source: Anonymous, 2007) 


\section{Consumption pattern of Gundpak}

Demographics of the respondents, who consumed Gundpak regularly, are presented in the Table 5.

Table 5. Consumption pattern of Gundpak according to religion, age and sex

\begin{tabular}{lllc} 
& \multicolumn{2}{c}{$($ Respondents, $\mathrm{n}=180)$} \\
\hline Demographics & \% & Demographics & \% \\
\hline$\underline{\text { Age group }}$ & & Caste/Tribe & \\
$15-35$ & 83.3 & Newar & 70.6 \\
$35-55$ & 13.9 & Brahmin & 15.6 \\
$55-75$ & 2.8 & Chettri & 6.1 \\
$>75$ & 0.0 & Limbu and Rai & 3.3 \\
& & Choudhary/Berma/ Yadav & 3.3 \\
& & Mangar & 1.1 \\
Gender & & Religion & \\
Male & 82.8 & Hindu & 83.3 \\
Female & 17.2 & Buddhist & 12.2 \\
& & Muslim & 2.8 \\
& & Christian & 1.7 \\
\hline
\end{tabular}

\section{Quality attributes of Gundpak}

Texture/body: According to the respondents' opinion, a soft texture Gundpak was highly preferred in different locations. The sugar, milk protein and fat are the main constituents, which greatly influence on the texture of Gundpak. The consistency of Gundpak is also affected by Gund, nuts and fruits. The texture mainly affect mouth feel, which is affected by sugar, Gund, spices, herbs, fruits and nuts that used in its manufacturing.

According to the survey result, $54.4 \%$ of respondents preferred a semi-soft textured Gundpak. In other hand; soft, semi-hard and hard were preferred by $28.9,16.7 \%$ and none respondent respectively.

Among the respondents ( $\mathrm{n}=180), 36.7 \%$ was noted that sugar was the main ingredient contributing the texture, whereas $28.9 \%$ noted that was contributed by Gund. Other ingredients that contributing the texture quality were noted as ghee, beaten rice, Khoa at $32,16,12$ and $2 \%$ respectively.

Appearance/Color: The color of Gundpak is developed naturally during cooking as noted by $52.2 \%$ of the respondents $(n=180)$, whereas $34.4 \%$ reported that the color was developed by sugar. Some respondents (10\%) noted that the color/ appearance were due to the artificially added color, whereas $3.3 \%$ was noted protein is responsible for color development in Gundpak.

Mouth-feel/Palatability: Ghee generally increased the palatability of the product. The palatability is important characteristics of Gundpak. Different ingredients used could impart on the palatability of product. According to the respondents $(\mathrm{n}=180)$, the palatability of Gundpak was influenced by ingredients used such as ghee, sugar, Gund, spices/ nuts, and flavor in percentage of $38.9 \%, 23.3 \%, 16.7$ $\%, 11.1 \%$ and $10 \%$ respectively. A $90 \%$ of respondents noted that, no any substance added for color, whereas $8.9 \%$ respondents noted that the added substance is responsible for color. However, about $1.1 \%$ respondents were unknown about it.

Taste/Flavor (odor/smell) : As per the survey data (respondents, $\mathrm{n}=180$ ), the sugar and ghee were found to be the major ingredients contributing $(51.1 \%)$ for taste and flavor of the product, whereas it is noted that Khoa, spices \& nuts and sugar contributed to $33.3 \%, 10 \%$ and $5.6 \%$ respectively.

\section{Storage and shelf- life of Gundpak}

Among the respondents $(\mathrm{n}=180), 64.4 \%$ of respondents reported that the shelf-life of Gundpak during summer season was one week, whereas $38.3 \%$ was reported two weeks in winter. Similarly, the shelf-life of Gundpak was reported for three, four and six weeks in winter by respondents of $27.8 \%$, $23.9 \%$ and $10 \%$ respectively. Therefore, the survey data clearly showed that the shelf-life of Gundpak in summer is one week and 2 week in winter.

\section{Consumption pattern based on age or group of respondents}

According to the respondents $(n=180), 65.6 \%$ of respondents were agreed that all demographic pattern such as sex, age and groups are preferred Gundpak. Respondents at the percentage of $15.6 \%, 7.8 \%, 6.7 \%, 3.3 \%$ and $1.1 \%$ reported that Gundpak is preferred by other groups such as children, old, adult, very old and adolescent respectively.

\begin{tabular}{|c|c|c|}
\hline Municipality & Location & $\begin{array}{c}\text { Annual } \\
\text { production (MT)* }\end{array}$ \\
\hline Kavre & Banepa(Halwai's shop) & 6.5 \\
\hline \multirow[t]{6}{*}{ Bhaktapur } & Kamalbinayak & 9.9 \\
\hline & Taumadi & 9.5 \\
\hline & Nawadurga hall & 19.9 \\
\hline & Suryabinayak & 20.1 \\
\hline & Halwai's shops & 23.7 \\
\hline & Sub-total & 89.6 \\
\hline \multirow[t]{4}{*}{ Madhyapur Thimi } & Nagadesh & 10.4 \\
\hline & Gatthaghar & 2.1 \\
\hline & Halwai's shops & 3.4 \\
\hline & Sub-total & 15.9 \\
\hline \multirow[t]{6}{*}{ Kathmandu } & Tahachal & 207.3 \\
\hline & Naradevi & 24.3 \\
\hline & Asan & 16.7 \\
\hline & Naya Baneshwor & 28.4 \\
\hline & Halwai's shops & 32.7 \\
\hline & Sub-total & 325.3 \\
\hline \multirow[t]{6}{*}{ Lalitpur } & Chappagaun & 79.7 \\
\hline & Lagankhel & 20.4 \\
\hline & Mangal Bazzar & 24.6 \\
\hline & Halwai's shops & 23.6 \\
\hline & Sub -total & 148.3 \\
\hline & Grand total & 579.1 \\
\hline
\end{tabular}

*The production data are mean of five respondents in each location 


\section{Production and sales volume of Gundpak}

A tentative production and sales volume of Gundpak in Kathmandu valley is presented in Table 6 and 7 respectively.

From the data of total production and selling, it has been found that there is a deficit in selling at amount of 21.6MT annually, which might be due to local consumption and sales of the product.

Table 7. Tentative sales volume of Gundpak at different locations of Kathmandu valley

\begin{tabular}{|c|c|c|}
\hline Kavre & & $\begin{array}{c}\text { Annual Sales } \\
\text { (MT)* }\end{array}$ \\
\hline & $\begin{array}{l}\text { Banepa (Halwai's } \\
\text { shop) }\end{array}$ & 5.4 \\
\hline \multicolumn{3}{|c|}{ Bhaktapur } \\
\hline & Kamalbinayak & 20.3 \\
\hline & Taumadi & 23.8 \\
\hline & Suryabinayak & 14.5 \\
\hline & Nawa Durga Hall & 6.7 \\
\hline & Datta Traya & 9.5 \\
\hline & Sub-total & 80.2 \\
\hline \multicolumn{3}{|c|}{ Madhyapur Thimi } \\
\hline & Nagadesh & 26.9 \\
\hline & Gattaghar & 1.7 \\
\hline & Sub-total & 28.6 \\
\hline \multicolumn{3}{|c|}{ Lalitpur } \\
\hline & Lagankhel & 22.5 \\
\hline & Mangal Bazzar & 16.6 \\
\hline & Patan Dhoka & 1.5 \\
\hline & $\begin{array}{l}\text { Sub-total } \\
\end{array}$ & 40.6 \\
\hline \multicolumn{3}{|c|}{ Kathmandu } \\
\hline & New Road & 225.9 \\
\hline & Asan & 31.9 \\
\hline & Naradevi & 25.3 \\
\hline & Naya bus park & 24.2 \\
\hline & Nayabaneswor & 10.5 \\
\hline & Maitidevi & 6.7 \\
\hline & Kalanki & 47.1 \\
\hline & Gausala & 5.2 \\
\hline & Koteshwor & 3.7 \\
\hline & Kalimati & 7.8 \\
\hline & Machhapokhari & 1.3 \\
\hline & Tripureswor & 3.8 \\
\hline & Sundhara & 7.6 \\
\hline & $\begin{array}{l}\text { Sub-total } \\
\end{array}$ & 401 \\
\hline & Grand total & 550.4 \\
\hline
\end{tabular}

*Data are the average of five respondents in each location

\section{Effects of seasons and galas}

In the previous days Gundpak was mainly produced and sales in the winter because of its storage problem. However, it is produced and sold throughout the year. According to the survey report, the sales of Gundpak was found exceptionally high in different galas like Matatirtha Aunshi and Kushe Aunshi, Teej, Dashain and Tihar, etc.

\section{Conclusion}

Gundpak is a popular traditional Khoa based milk product produced at cottage scale in Kathmandu valley of Nepal. Some varieties of Gundpak can also be taken as a functional food. Khoa is a major raw material for Gundpak production and the amount of Khoa sold in the Kathmandu valley was approximately equal to 5.4 million $\mathrm{kg}$ per year and it cost around to NRs. 1450 million. About 30-35 \% of Khoa is used for Gundpak production and remaining is used for other sweets. In this survey, the production and sales of Gundpak in different locations of valley was investigated by developing the pretested questionnaire. Still the majority of producers are found to be selling their products in open trays called Kisti. Now a day, there is a development in trend to package the Gundpak into LDPE and HDPE trays having capacity of half to one kilogram. According to the producers and sellers, the self-life of the products depends on seasonal variability. Additionally, the survey data revealed that it has a shorter shelf-life i.e. one week for summer and two weeks for winter season. From this study work the following recommendations could be drawn for further scientific study.

- Optimization of ingredients and process for Gundpak production

- Study on the shelf-life of product under the suitable packaging materials

- Consumers' health safety and risk analysis for such a dairy products

Detail analysis of micro-nutrients as well as other functional properties e.g. amino acids profile, vitamins, fatty acid profile, minerals and any other functional properties of Gundpak

\section{Acknowledgements}

The first author would like to express his sincere gratitude toward the Institute of Science and Technology, Dean's Office and Central Department of Food Technology, Dharan for giving the opportunity to carry out this research work. Authors are also grateful to University Grant Commission, T.U. for providing the financial assistance to this work. Similarly, the authors are also thankful to all the producers and sellers of Gundpak, who actively participated in survey study regarding on consumption, marketing and preference of Gundpak. 


\section{Glossary of local terminology}

Baidhya-A person, who involved in the treatment of patients by using herbal medicine

Battisa powder-A grinded powder consisting of 32 medicinal and herbal plants mixed together in different proportions

Dashain - Hindu's greatest festival

Halwai - an ethnic community, who are involved in making sweets traditionally as their profession,

Jamara- Tender shoots of barley or other cereal grains sprouted in dark place, which is golden yellow in color and offered with Tika on the occasion of Dashain by Hindu people as blessing of goddess Durga.

Karai- a frying or cooking vessels made up of iron or aluminum

Khoa- a concentrate milk product

Kisti- a tray made up of metal like aluminum, iron, and stainless steel

Masala-Powder of some medicinal plants

Matatirtha aunshi and Kushe aunshi- Similar to mother's and father's day

Misri - Sugar candy, large crystals formed on a string

Newari- an ethnic community of Nepal

Pakh - in Newari it means cooked

Pakhuna jwala or Pakhu bansa - Medicinal or Sutkeri Gundpak cooked with Mishri and other ingredients

Sutkeri - Women just after giving birth to the baby

Teej-Teej festival is an important festival for married Hindu women and much anticipated monsoon festival

Tihar - A second greatest festival of Nepal also known as 'Dipawali' means festival of lighting

Tika-A mixture of rice with curd and red color (Abir), which is put on forehead by elders or respected persons as blessings of god Durga.

\section{References}

Acharya P. P. and Sapkota P. (2008). Effect of Processing Temperature and Ingredients in the Preparation of Gundpak-A Khoa Based Dairy Product, Nepal J. of Sci. and Tech., (9):57-64

Aneja R. P., B. N. Mathur R. C. Chandan and Banerjee A. K. (2002). Technology of Indian Milk Products, Handbook on Process Technology Modernization for Professionals, Entrepreneurs and Scientists, a Dairy India Publication, Delhi, India. pp 7, 81-87.

Anonymous (2007). Medicinal plants of Nepal (Revised), Bulletin of the Department of Plant Resources No. 28, Government of Nepal, Ministry of Forest and Soil Conservation, Department of Plant Resources, Thapathali, Kathmandu, Nepal.

Anonymous (2010). Plant gums. Available in website: http:// www.fao.org/docrep/ x5326e/x5326e08.htm).
De S. (1983). Market Milk, Outlines of dairy technology, pp. 2, $382-466,273$

Gordon W.G. and Kalan E. B. (1987)). Proteins of milk. In: Web, B.H. Johnson, A.A. and Alford, J.A. (Eds). Fundamental of Dairy Chemistry, (2nd Ed), CBS publishes, pp. 102.

Gothwal P. P. and Bhavadasan M. K (1992). Studies on the browning characteristics in dairy products. Indian J. Dairy Sci., XLV (1): 146-151.

Maskey U. L. (2009). Personnel Communication, New Gundpak Bhandar, New Road Gate, Kathmandu.

Miller D. D. (1998). Food Chemistry, Laboratory Manual. John, Wiley and Sons Inc. New York, pp18

Nickerson T. A. (1987). Lactose, In: Fundamental of Dairy Chemistry, Webb, B.H., Johnson, A.H. and Alford, J.A., (Eds), pp 273-319.

Patel R. K. (1991). Indigenous milk products, Indian Dairy man, XLIII, (3): 120-125.

Prevention of food adulteration act, PFA (1954). Prevention of food adulteration act with Prevention of food adulteration rules, 1955 and commodity index with Exhaustive short notes (Amended Up-to-date), 24 $4^{\text {th }}$ edition, 2008, pp 287-288.

Rajendra G. M., Manjunath G. M and Bhatt G. S. (1991). Producing of 5-Hydroxy Methyl-2-furfural during preparation of Khoa, J. Food Sci. Tech., 28(3): 177-178.

Rajendra G. M., Manjunath G. M and Bhatt G. S. (1991). Producing of 5-Hydroxy Methyl-2-furfural in dairy products. Indian J. Dairy Sci., XLV (1): 146-151.

Rajorhia G. S. (2002). Opportunities in production and marketing of Khoa and its packaging, Technical SessionII, Indian Dairyman, 78-83

Ranganna S. (1986). Handbook of Analysis and Quality Control for Fruits and Vegetables Products, 2nd Ed., Tata McGraw-Hill Publishing Company Limited, New Delhi, pp 320-329.

Sharma N. P. (2007). Process optimization for the preparation of Khoa based indigenous product Gundpak. Master Dissertation, Faculty of science and Technology, Purbanchal University, Kathmandu

Shrestha R. K. (2009). Personnel Communication, Baidhaya Pasal, Mangal Bazzar, Lalitpur.

Suresh I. and Jha Y. K. (1994). Optimization of the process for Kalakand manufacturing and extension of its shelf life. $J$. Food Sci. Tech., 195: 389-394. 